\title{
THE IMPACT OF CUSTOMERS' PERCEPTION OF CSR ON CORPORATE BRAND LOYALTY: THE CASE OF THE ROMANIAN MOBILE TELECOM INDUSTRY
}

Moisescu, O. I.

\begin{abstract}
The goal of the current research is to analyze the impact of customers' perceptions of corporate social responsibility (CSR) on their loyalty towards mobile telecommunication companies within the particular socio-cultural and economic context of one of the largest national markets of Central and Eastern Europe. In order to achieve this goal, a survey was conducted among a sample of 1,464 mobile telecommunication customers from the urban area of Romania. The findings point out the fact that Romanian mobile telecom customers' loyalty is not significantly impacted by how they perceive their service suppliers' responsibilities with regard to their employees or economic success, while their perceptions of companies' responsibilities towards customers, public authorities, the environment, community development, and sponsorship have a significant impact on corporate brand loyalty. The findings have managerial implications in what concerns the appropriate implementation and communication of CSR policies by mobile telecommunication companies from the region in order for them to enhance their customer's loyalty.
\end{abstract}

Keywords: CSR; customer loyalty; mobile telecommunication

JEL classification: M31

\section{Introduction}

In the current economic context, both corporate social responsibility (CSR) and brand loyalty represent important theoretical and practical issues, especially due to the fact that they can produce several benefits for organizations. Thus, CSR has been proven to enhance employee attraction and retention (Kim and Park, 2011), as well as relationships with customers and other stakeholders (Peloza and Shang, 2011), most consumers expecting companies to engage in CSR (Becker-Olsen et al., 2006), and taking this engagement into consideration when purchase decisions are made (Brown and Dacin, 1997). Brand loyalty, on the other hand, has been proven to be positively associated with business performance (Reichheld, 2003) and long-term profitability (Salegna and Goodwin, 2005).

For the last few decades, much attention has been given in literature to the topics of CSR and brand loyalty, as well as to the relationship between consumers' behavior and their perceptions of CSR. However, further and deeper investigation of the impact of perceived CSR on brand loyalty is needed. Moreover, little is known about the existence and nature of such a relationship within the particular context of Central and Eastern European countries; the mobile telecommunication sector being no exception to this lack of regional knowledge. The goal of the current research is to analyze the impact of customers' perceptions of corporate social responsibility (CSR) on their loyalty towards mobile telecommunication companies within the specific socio-cultural and economic context of one of the largest national markets of Central and Eastern Europe. 


\section{Literature Review}

Despite the fact that the definition of the concept of CSR is still under debate in the literature (Dahlsrud, 2008; Freeman et al., 2010), there are three main approaches regarding the systematization of the concept. Thus, we have Carroll's (1979) approach in which CSR is seen as a four-dimensional concept encompassing economic, legal, ethical and discretionary (philanthropic) organizational responsibilities, the sustainable development based approach in which CSR is regarded as a three-dimensional structure, including economic, environmental and social responsibilities, and, respectively, the stakeholder based approach (Freeman et al., 2010) in which CSR is systematized as a multi-dimensional construct including responsibilities towards shareholders, customers, employees, the environment, the society and other relevant stakeholders.

Regarding the concept of brand loyalty, the main issues regarding its definition relate to its exclusive versus non-exclusive nature and, respectively, to its behavioral and/or attitudinal character. The American Marketing Association (AMA), as well as brand "guru" David A. Aaker adopt a mostly exclusive and behavioral approach when defining brand loyalty, relating it to the situation in which a consumer generally buys the same manufacturer-originated product repeatedly over time rather than buying from multiple suppliers within the category (AMA), or to the likelihood that a consumer would switch to another brand, especially when that brand makes a change in price, product, communication, or distribution (Aaker, 1991). On the other hand, Jacoby and Chestnut (1978) approach the concept in a more holistic manner, defining it as the biased behavioral response expressed over time by consumers with respect to one or more alternative brands out of a set of brands, being a function of psychological processes. This latter definition enjoys widespread support in the marketing literature and is the most often used in brand loyalty research, as it clearly states that brand loyalty is not necessarily exclusive, being reflected by both repeat buying behavior and psychological commitment.

After exploring the literature comprised in Web of Science and Scopus, the most frequently used databases for searching the literature (Norris and Oppenheim, 2007; Chadegani et al., 2013), several relevant and specific studies regarding the relationship between customers' perceptions of CSR and brand loyalty in the mobile telecommunication industry have been identified. Thus, Salmones et al. (2005) studied the impact of perceived CSR (considering economic, legal, ethical and social aspects) on the overall evaluation of the service and brand loyalty, conducting a survey among 689 mobile telecom services users from Spain. The authors concluded that there isn't any direct relation between CSR perceptions and consumer loyalty towards the firm, but perceived CSR influences loyalty indirectly via the overall valuation the user makes of the service received. Vlachos et al. (2009) surveyed 830 randomly selected mobile telecom customers from Greece in order to investigate whether consumers' perceptions of CSR motives influence their evaluation of CSR efforts, revealing that appropriately motivated CSR actions positively affect trust, and indirectly, customer loyalty, regardless of the performance of the firm on service quality provision. Ali et al. (2010) investigated 250 young customers of mobile telecommunication companies from Pakistan in order to analyze the linkage between perceived CSR and service quality and, respectively, customer satisfaction, purchase intention and retention. Surprisingly, the authors found no linkage between perceived CSR and customer purchase intentions and retention. Moreover, even if a significant relationship was found between service quality and customer satisfaction, no relationship was detected between customer 
satisfaction and purchase intention and retention. However, a more recent survey conducted by $\mathrm{He}$ and $\mathrm{Li}$ (2011) among 268 customers of mobile telecommunication services from Taiwan revealed that both CSR and service quality have direct effects on brand identification and customer satisfaction, and, respectively, indirect effects on service brand loyalty (via brand identification and customer satisfaction).

The same literature sources reveal other relevant studies regarding the relationship between customers' perceptions of CSR and brand loyalty which, even though not focused on the specific context of the mobile telecommunication industry, bring important insights from a multi-sectorial perspective. Thus, Maignan et al. (1999), after surveying two independent samples of 229 and, respectively, 154 marketing executives of companies from different industries in the US, showed that according to marketing executives' statements, corporate citizenship (reflected by economic, legal, ethical and discretionary aspects) positively affects employee commitment, customer loyalty, and business performance. Moreover, Stanaland et al. (2011), after investigating 443 US customers of companies from several industries, found that perceived CSR (measured as commitment to ethics principles, respect to employees, long-term success, and playing a role in our society that goes beyond the mere generation of profits) impacts perceptions of corporate reputation, consumer trust, and loyalty. Last but not least, Lee et al. (2012), after conducting a survey among 250 young female customers of companies from several industries from Korea and focusing on the philanthropic side of CSR, showed that the perceived fit between consumers' lifestyles/values and CSR activities influences the actual perceptions of CSR activities which, in turn, positively impact customer loyalty, both directly and indirectly (mediated by consumer-company identification).

\section{Methods}

The goal of the current research is to analyze the impact of customers' perceptions of corporate social responsibility (CSR) on their loyalty towards mobile telecommunication companies within the particular socio-cultural and economic context of one of the largest national markets of Central and Eastern Europe. In order to achieve this goal, a survey was conducted among a sample of 1464 mobile telecommunication customers from the urban area of Romania, between January-March 2015, based on a paper and pencil (self-administered) questionnaire which comprised 28 items intended to measure CSR perceptions and six items for the quantification of customer loyalty in the analyzed sector.

The final item pool (Table 1) used in order to assess CSR perceptions and customer loyalty was set after a two-phase process. Thus, in the first phase, a preliminary item pool was generated after a comprehensive literature review concerning the quantification of consumers' perception of CSR and corporate brand loyalty. In the second phase, the preliminary item pool was purified with the help of several marketing professors, $\mathrm{PhD}$ and MA students, by identifying and removing those items which were considered ambiguous, redundant or imperceptible to customers. Respondents were asked to mention a specific mobile telecommunication company of which they were customers, and further on, to refer to it and to state their perceptions regarding that company's CSR ("I believe that this company ..."), rating each of the 28 CSR items on a Likert scale ranging from 1="strongly disagree" to 7="strongly agree", with a middle/neutral point reflecting the lack of an established perception. The respondents were further asked to refer to the same company and to assess their corporate brand loyalty using six items and a similar Likert scale. 
Table 1 | The final item pool for assessing perceptions of CSR and brand loyalty

\begin{tabular}{|c|c|c|}
\hline Items & & Sources* \\
\hline CSR1 & Strives to maximize profits and improve economic and financial performance & {$[1,2,3,4]$} \\
\hline CSR2 & Pursues its success in the long-term, not only in the short-term & {$[1,2,3,4]$} \\
\hline CSR3 & Strives to offer its customers products/services of reasonable quality & {$[2]$} \\
\hline CSR4 & Is concerned with its customers' satisfaction & {$[3,5]$} \\
\hline CSR5 & Provides customers with honest and complete information about its products/services & {$[2,3,5,6]$} \\
\hline CSR6 & Charges fair and reasonable prices for its products/services & {$[2,6]$} \\
\hline CSR7 & Provides safe products/services, not-threatening to physical/mental health of buyers & {$[2,6]$} \\
\hline CSR8 & Works diligently to handle and solve its customers' complaints & {$[2,3]$} \\
\hline CSR9 & Pays its employees fairly and in a reasonable manner & {$[2,3,6]$} \\
\hline CSR10 & Offers its employees decent working conditions & {$[2,3,6]$} \\
\hline CSR11 & Does everything possible to prevent and avoid discrimination of employees & {$[2,3,6]$} \\
\hline CSR12 & Respects the rights of its employees & {$[1,2,5]$} \\
\hline CSR13 & Treats its employees with respect & [6] \\
\hline CSR14 & Provides professional development and promotion opportunities to its employees & {$[2,3,5]$} \\
\hline CSR15 & Does everything possible to reduce its negative effects on the natural environment & {$[2,3,5,6]$} \\
\hline CSR16 & Strives to minimize the consumption of resources that affect the natural environment & {$[2]$} \\
\hline CSR17 & Works diligently to use environmentally friendly materials & {$[2,3,5,6]$} \\
\hline CSR18 & Is concerned with the proper management of waste and recycling activities & {$[2,6]$} \\
\hline CSR19 & Contributes to the economic growth and development of the region & {$[2]$} \\
\hline CSR20 & Contributes to the long-term welfare and life quality of people in the region & {$[1,3,4,5]$} \\
\hline CSR21 & Creates and sustains jobs in the region & {$[2]$} \\
\hline CSR22 & Contributes to the development of other companies in the region & {$[2]$} \\
\hline CSR23 & Respects the values, customs and culture of the region & {$[2]$} \\
\hline CSR24 & Supports charitable and social projects addressed to the disadvantaged & {$[1,2,3,4,5]$} \\
\hline CSR25 & Supports cultural and social events (music, sports, etc.) & {$[3,4]$} \\
\hline CSR26 & Fully complies with the legislation in conducting its activities & {$[1,4,5,6]$} \\
\hline CSR27 & Always pays state taxes in a fairly and honestly manner & {$[5,6]$} \\
\hline CSR28 & Does everything possible to prevent and avoid corruption in its relation with the state & [6] \\
\hline LOY 1 & I consider myself a loyal customer of this company & {$[9,10]$} \\
\hline LOY2 & This company is my first choice, compared to others in the sector & {$[8,11]$} \\
\hline LOY3 & I will continue to be a customer of this company & {$[7,8]$} \\
\hline LOY4 & In the future I plan to purchase more from this company & [11] \\
\hline LOY5 & I would recommend this company to my friends and acquaintances & {$[7,8,11]$} \\
\hline LOY6 & I wouldn't give up being a customer even if a competitor came up with a better offer & [11] \\
\hline
\end{tabular}

* [1] Maignan, 2001; [2] Öberseder et al., 2014; [3] Pérez and Bosque, 2013; [4] Salmones et al., 2005; [5] Turker, 2009; [6] Wagner et al., 2008; [7] Cronin et al., 2000; [8] Martínez and Bosque, 2013; [9] Rosenbaum, 2006; [10] Sloot et al., 2005; [11] Zeithaml et al., 1996 
Regarding the sampling procedure, two non-probability sampling techniques were combined - snowball sampling and quota sampling by gender and age - in order to collect data from a sample with a demographic structure which had to be diversified and similar to the actual population structure (Table 2). After auditing the collected data, the final investigated sample was comprised of 1464 mobile telecommunication services customers, from all the main competitors active on the Romanian market: 1096 customers of Orange, 115 customers of Telekom, 213 customers of Vodafone and 40 customers of Digi.

Table 2 | Sample structure considering age and gender

\begin{tabular}{|l|c|c|c|}
\hline & Men & Women & TOTAL \\
\hline $\mathbf{1 8 - 2 4}$ years & $7.99 \%$ & $12.30 \%$ & $20.29 \%$ \\
\hline $\mathbf{2 5 - 2 9}$ years & $8.88 \%$ & $8.88 \%$ & $17.76 \%$ \\
\hline $\mathbf{3 0 - 3 4}$ years & $6.90 \%$ & $5.05 \%$ & $11.95 \%$ \\
\hline 35-39 years & $5.67 \%$ & $6.01 \%$ & $11.68 \%$ \\
\hline $\mathbf{4 0 - 4 4}$ years & $5.60 \%$ & $6.22 \%$ & $11.82 \%$ \\
\hline $\mathbf{4 5 - 4 9}$ years & $6.42 \%$ & $6.49 \%$ & $12.91 \%$ \\
\hline 50-56 years & $7.79 \%$ & $5.81 \%$ & $13.59 \%$ \\
\hline TOTAL & $49.25 \%$ & $50.75 \%$ & $100.00 \%$ \\
\hline
\end{tabular}

Source: author

From a methodological operationalization perspective, the large number of observable variables (items) had to be reduced to a significantly reduced number of reflective latent variables (components). For this purpose, an exploratory factor analysis revealed the fact that the six loyalty indicators can be adequately grouped into one single latent variable, while the 28 perceived CSR items can be appropriately clustered into seven components: responsibilities towards economic success, customers, employees, the environment, community development, sponsorship, and public authorities (Table 3). Furthermore, a score was computed for each latent variable as the average of the reflecting items' values.

Considering the paper's main goal, a multiple linear regression model was further proposed (Figure 1), a model in which the latent variables regarding CSR perceptions were considered predictors (independent variables), while the latent variable corresponding to customer loyalty was treated as a dependent variable. 
Table 3 | Latent variables: perceptions of CSR and brand loyalty

\begin{tabular}{|l|c|c|}
\hline Latent variables & Items & Variance explained \\
\hline Economic success & CSR1-2 & $4.849 \%$ \\
\hline Customers & CSR3-8 & $9.647 \%$ \\
\hline Employees & CSR9-14 & $12.439 \%$ \\
\hline Environment & CSR15-18 & $8.267 \%$ \\
\hline Community development & CSR19-23 & $8.419 \%$ \\
\hline Sponsorship & CSR24-25 & $4.916 \%$ \\
\hline Public authorities & CSR26-28 & $6.314 \%$ \\
\hline Customer loyalty & LOY1-6 & $10.942 \%$ \\
\hline
\end{tabular}

(Exploratory factor analysis with Varimax rotation; Excellent sampling adequacy: KMO=.929>.9; Correlations appropriate for factor analysis: Bartlett's test of sphericity Chi-square $=24845.259, \mathrm{df}=561, \mathrm{p}<.001$; Total variance explained $=65.795 \%$ )

Source: author

Figure 1 | Proposed model for the impact of perceived CSR on brand loyalty

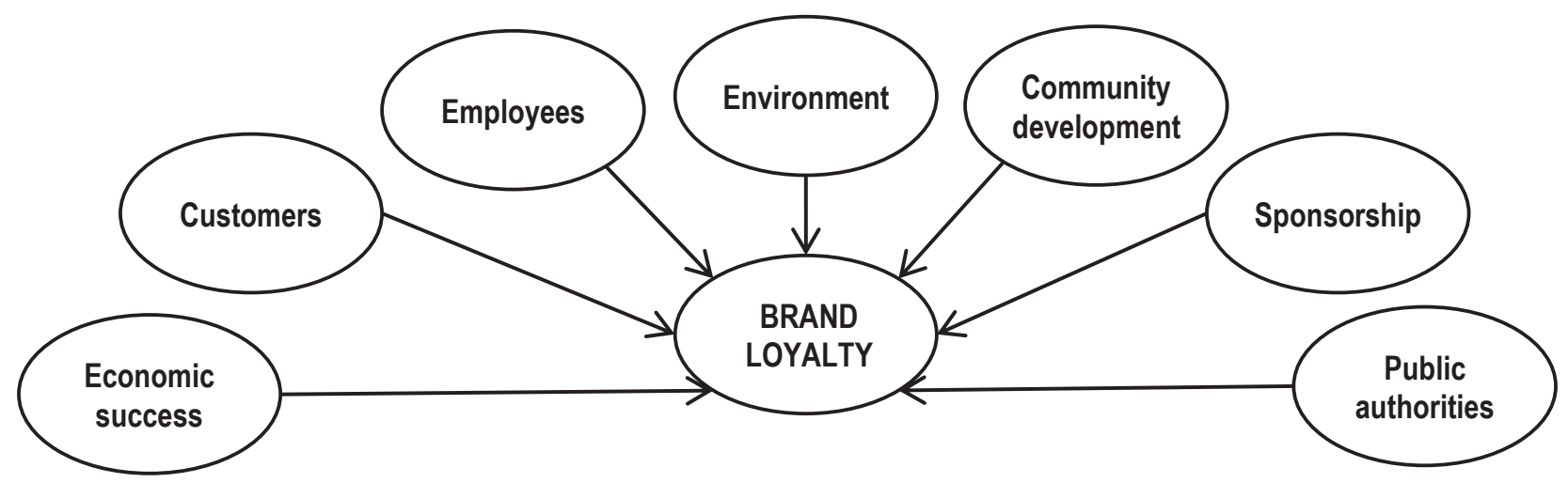

Source: author

\section{Results}

Firstly, the latent variables' scores were used for a comparative analysis of customers' perception of CSR, according to specific CSR domains, for the main competitors of the Romanian mobile telecommunication industry - those competitors that were most frequently referred to by respondents (Table 4). Using the proposed perceived CSR quantification instrument as a benchmarking tool for companies in the analyzed sector, we were able to outline the Romanian mobile telecommunication companies perceived by their own customers as being the most socially responsible: Telekom, in what concerns economic success, customers, employees, the environment, and public authorities; Vodafone, with respect to the environment and sponsorship; and, Orange, considering community development. The analysis suggests that companies perceived as being more socially responsible (Telekom, in this case) have higher customer loyalty mean scores. 
Table 4 | Customers' perceptions of CSR for the main competitors in the Romanian mobile telecommunication industry

\begin{tabular}{|l|c|c|c|}
\hline & Orange & Vodafone & Telekom \\
\hline Economic success & 5.77 & 5.77 & 5.93 \\
\hline Customers & 4.99 & 5.13 & 5.27 \\
\hline Employees & 4.60 & 4.61 & 4.67 \\
\hline Environment & 4.51 & 4.57 & 4.57 \\
\hline Community development & 4.81 & 4.76 & 4.75 \\
\hline Sponsorship & 4.93 & 5.06 & 5.05 \\
\hline Public authorities & 4.60 & 4.77 & 4.81 \\
\hline Brand loyalty & $\mathbf{5 . 0 3}$ & $\mathbf{4 . 9 8}$ & $\mathbf{5 . 1 0}$ \\
\hline
\end{tabular}

Note: Mean scores. Initial measurements on a Likert scale ranging from 1 to 7

Source: author

Secondly, in order to test the proposed model, a multiple linear regression analysis was conducted (Table 5). The resulted coefficient of multiple determination suggests that a significant amount of the variance in the dependent variable is accounted for by the proposed model's predictors $\left(\mathrm{R}^{2}=.365\right)$. Moreover, according to the corresponding ANOVA test's results $(\mathrm{F}(7,1456)=119.78, \mathrm{p}<.001)$ the model's $\mathrm{R}^{2}$ differs significantly from zero. Thus, it can be stated that $36.5 \%$ of the variance in corporate brand loyalty in the Romanian mobile telecommunication market is accounted for by the seven dimensions of customers' perceptions of CSR.

Table 5 | Multiple linear regression coefficients

\begin{tabular}{|l|c|c|c|c|c|}
\hline & \multicolumn{2}{|c|}{$\begin{array}{c}\text { Unstandardized } \\
\text { Coefficients }\end{array}$} & $\begin{array}{c}\text { Standardized } \\
\text { Coefficients }\end{array}$ & \multirow{2}{*}{ t } & p \\
\cline { 2 - 4 } & B & Std. Error & Beta & & \\
\hline (Constant) & .431 & .202 & & 2.137 & .033 \\
\hline Economic success & .012 & .027 & .010 & .436 & .663 \\
\hline Customers & .535 & .031 & .443 & 16.997 & .000 \\
\hline Employees & -.002 & .039 & -.002 & -.056 & .955 \\
\hline Environment & .117 & .035 & .088 & 3.311 & .001 \\
\hline Community development & .102 & .035 & .077 & 2.888 & .004 \\
\hline Sponsorship & .054 & .026 & .050 & 2.058 & .040 \\
\hline Public authorities & .121 & .034 & .094 & 3.539 & $\mathbf{. 0 0 0}$ \\
\hline
\end{tabular}

Source: author 
The multiple linear regression coefficients in Table 5 reveal the fact that corporate brand loyalty in the mobile telecommunication industry is not significantly impacted by how customers perceive companies' responsibilities with regard to their employees $($ Beta $=-.002 ; p=.955)$ and economic success (Beta $=.010 ; p=.663)$. However, all other perceptions of CSR have a significant impact on customer loyalty - the most important being how customers perceive companies' responsibility towards their customers (Beta $=.443 ; \mathrm{p}<.001)$, followed by how customers perceive companies' responsibilities towards public authorities (Beta $=.094 ; \mathrm{p}<.001)$, the environment (Beta $=.088 ; \mathrm{p}=.001)$, community development (Beta $=.077 ; \mathrm{p}=.004)$, and, respectively, $\operatorname{sponsorship}(\mathrm{Beta}=.050$; $\mathrm{p}=.040)$.

\section{Conclusions, Managerial Implications and Future Research}

The current paper manages to fill a regional knowledge deficiency by investigating the impact of customers' perceptions of CSR on their loyalty towards mobile telecommunication companies from one of the largest national market of Central and Eastern Europe. The findings point out the fact that Romanian mobile telecommunication customers' loyalty is not significantly impacted by how they perceive their service providers' responsibilities with regard to their employees or economic success, while their perceptions of companies' responsibilities towards their customers, public authorities, the environment, community development, and sponsorship have a significant impact on loyalty.

The managerial implications of these findings are relevant both from a CSR adoption and implementation perspective, and from a marketing communication standpoint. Considering that customers' perceptions of CSR are derived from their exposure to certain information sources (personal, commercial, public and experience), mobile telecommunication companies that operate in the Romanian market and are interested in increasing their customers' loyalty should actively communicate and disclose their CSR policies and actions through commercial and public channels, emphasizing those categories of responsibilities which have a significant impact on brand loyalty. Their responsibility towards customers should be the main focus, this referring to aspects such as being concerned with customers' satisfaction, solving customers' complaints, charging fair and reasonable prices, and providing high quality and safe products, along with honest and complete information about them. CSR policies and actions regarding public authorities, the environment, community development and sponsorship should also be actively disclosed. Thus, companies should emphasize the fact that they comply with the legislation, pay taxes in a fair and honestly manner, and prevent/avoid corruption in their relation with the state. Moreover, issues related to reducing business operations' effects on the natural environment, minimizing the consumption of resources, using environmentally friendly materials, as well as proper waste management and recycling should be also outlined in order to convey environmental responsibility. Community development issues should also be emphasized by pointing our companies' contributions to local economic growth, development of local companies and creation and maintenance of local jobs, as well as their positive effects on the long-term welfare and life quality of people in the region. Finally, any support given to social projects, or to cultural or social events should be also actively disclosed. 
The main limitations of this paper are given by the fact that potential mediating factors of the relationship between customers' perceptions of CSR and customer loyalty were not included in the proposed and tested mode. Thus, as a future research opportunity, the current analysis should be extended by taking into consideration several mediating variables such as customer satisfaction, customer trust, company-consumer identification, price-quality competitive positioning, and/or perceived switching costs, and integrating them into a structural equation model along with perceptions of CSR as exogenous variables and customer loyalty as an endogenous variable. Moreover, another research limitation and at the same time opportunity for future research refers to including demographics such as gender, age, income, education, or type of residence into the model.

\section{References}

Aaker, D. A. (1991). Managing Brand Equity: Capitalizing on the Value of a Brand Name. New York: The Free Press.

Ali, I., Rehman, K. U., Yilmaz, A. K., Nazir, S. \& Ali, J. F. (2010). Effects of corporate social responsibility on consumer retention in cellular industry of Pakistan. African Journal of Business Management, 4(4), 475-485.

Becker-Olsen, K.L., Cudmore, B. A., \& Hill, R. P. (2006). The impact of perceived corporate social responsibility on consumer behavior. Journal of Business Research, 59(1), 46-53.

Brown, T. J., \& Dacin, P. A. (1997). The company and the product: corporate associations and consumer product responses. The Journal of Marketing, 61(1), 68-84.

Carroll, A. B. (1979). A Three-Dimensional Conceptual Model of Corporate Performance. Academy of Management Review, 4(4), 497-505.

Cronin Jr, J. J., Brady, M. K., \& Hult, G. T. M. (2000). Assessing the effects of quality, value, and customer satisfaction on consumer behavioral intentions in service environments. Journal of Retailing, 76(2), 193-218.

Dahlsrud, A. (2008). How corporate social responsibility is defined: an analysis of 37 definitions. Corporate social responsibility and environmental management, 15(1), 1-13.

Freeman, R. E., Harrison, J. S., Wicks, A. C., Parmar, B. L., \& De Colle, S. (2010). Stakeholder theory: the state of the art. Cambridge: Cambridge University Press.

He, H., \& Li, Y. (2011). CSR and service brand: The mediating effect of brand identification and moderating effect of service quality. Journal of Business Ethics, 100(4), 673-688.

Jacoby, J., \& Chestnut, R. W. (1978). Brand Loyalty: Measurement and Management. John Wiley and Sons, New York.

Kim, S. Y., \& Park, H. (2011). Corporate social responsibility as an organizational attractiveness for prospective public relations practitioners. Journal of Business Ethics, 103(4), 639-653.

Lee, E. M., Park, S. Y., Rapert, M. I. and Newman, C. L. (2012). Does perceived consumer fit matter in corporate social responsibility issues? Journal of Business Research, 65(11), 1558-1564.

Maignan, I. (2001). Consumers' perceptions of corporate social responsibilities: a cross-cultural comparison. Journal of Business Ethics, 30(1), 57-72.

Maignan, I., Ferrell, O. C, \& Hult, G. T. M. (1999). Corporate citizenship: cultural antecedents and business benefits. Journal of the Academy of Marketing Science, 27(4), 455-469.

Martínez, P., \& Del Bosque, R. I. (2013). CSR and customer loyalty: The roles of trust, customer identification with the company and satisfaction. International Journal of Hospitality Management, 35, 89-99. 
Norris, M., \& Oppenheim, C. (2007). Comparing alternatives to the Web of Science for coverage of the social sciences' literature. Journal of Informetrics, 1(2), 161-169

Chadegani, A. A., Salehi, H., Yunus, M. M., Farhadi, H., Fooladi, M., Farhadi, M., \& Ebrahim, A. N. (2013). A comparison between two main academic literature collections: Web of Science and Scopus databases. Asian Social Science, 9(5), 18-26.

Öberseder, M., Schlegelmilch, B. B., Murphy, P. E., \& Gruber, V. (2014). Consumers' Perceptions of Corporate Social Responsibility: Scale Development and Validation. Journal of Business Ethics, 124(1), 101-115.

Peloza, J., \& Shang, J. (2011). How can corporate social responsibility activities create value for stakeholders? A systematic review. Journal of the Academy of Marketing Science, 39(1), 117-135.

Pérez, A., \& Del Bosque, I. R. (2013). Measuring CSR image: three studies to develop and to validate a reliable measurement tool. Journal of Business Ethics, 118(2), 265-286.

Reichheld, F. (2003). The one number you need to grow. Harvard Business Review, 82(6), 46-54.

Rosenbaum, M. S. (2006). Exploring the social supportive role of third places in consumers' lives. Journal of Service Research, 9(1), 59-72.

Salegna, G. J., \& Goodwin, S. A. (2005). Consumer loyalty to service providers. An integrated conceptual model. Journal of Consumer Satisfaction, Dissatisfaction and Complaining Behavior, 18(1), 51-67.

Salmones de los, M. G., Crespo, A. H., \& Bosque del, I. R. (2005). Influence of corporate social responsibility on loyalty and valuation of services. Journal of Business Ethics, 61 (4), 369-385.

Sloot, L. M., Verhoef, P. C., \& Franses, P.H. (2005). The impact of brand equity and the hedonic level of products on consumer stock-out reactions. Journal of Retailing, 81(1), 15-34.

Stanaland, A. J., Lwin, M. O., \& Murphy, P. E. (2011). Consumer perceptions of the antecedents and consequences of corporate social responsibility. Journal of Business Ethics, 102(1), 47-55.

Turker, D. (2009). Measuring corporate social responsibility: A scale development study. Journal of Business Ethics, 85(4), 411-427.

Vlachos, P. A., Tsamakos, A., Vrechopoulos, A. P., \& Avramidis, P. K. (2009). Corporate social responsibility: attributions, loyalty and the mediating role of trust. Journal of the Academy of Marketing Science, 37(2), 170-180.

Wagner, T., Bicen, P., \& Hall, Z. R. (2008). The dark side of retailing: towards a scale of corporate social irresponsibility. International Journal of Retail and Distribution Management, 36(2), 124-142.

Zeithaml, V. A., Berry, L. L., \& Parasuraman, A. (1996). The behavioral consequences of service quality. The Journal of Marketing, 60(1), 31-46.

\section{Author}

Ovidiu-loan Moisescu, Ph.D.

Associate Professor

Babeş-Bolyai University

Faculty of Economics and Business Administration

T. Mihali Street, No. 58-60, Code 400591

Cluj-Napoca, Romania

ovidiu.moisescu@econ.ubbcluj.ro

This work was supported from the European Social Fund through Sectorial Operational Programme Human Resources Development 2007-2013, project number POSDRU/159/1.5/S/142115, project title "Performance and Excellence in Postdoctoral Research in Romanian Economics Science Domain". 